\title{
Investigating the Challenges Faced by ESP Learners in Saudi EFL Context
}

\author{
Abdulaziz Nasser Alharthi \\ English Language Centre \\ Taif University \\ E-mail: analharthi99@gmail.com
}

Received: April 13, 2020 Accepted: April 27, 2020 Published: April 28, 2020

doi:10.5296/ijele.v8i2.16925 URL: https://doi.org/10.5296/ijele.v8i2.16925

\begin{abstract}
ESP courses are designed to meet the specific needs of students. With this regard, it is noted that there are many challenges and problems that encounter ESP students studying English for Business Administration at Taif University, Saudi Arabia. This study has two aims, the first one is to explore the problems faced by students and the second one is to find possible solutions in order to overcome these problems in the light of the views of the students. The main instruments that were used in this study were interviews and documents (results of final exams). To achieve the aims of this study, 5 Saudi male students majoring in Business Management and Administration, participated in this study. The results showed that students registered on the ESP business modules faced a variety of problems. The nature of such problems is divided into three categories: class size, the limitation of inputs, and classroom management.
\end{abstract}

Keywords: English for Specific Purposes, Pedagogy, learners' difficulties, large classes 


\section{Introduction:}

ESP is the teaching of English language with the object of enabling a learner to properly use it in his field (Paltridge and Starfield, 2013). This study dates back to classical period (Hutchinson, 1987). The significance of the field has significantly enhanced since 1960s (Howatt, 1984). Specifically since 1970s and 1980s, it has occupied very important place (Kennedy, 2012). According to Hutchinson and Waters, three leading causes of ESP as an approach are increased need for the English skills in a particular field and progress in linguistics and in educational psychology.

\subsection{Issues and Problems in ESP Classes}

Many researchers have investigated various problems that face ESP learners from different angles. For example, Tabatabaei and Mokhtari (2014) investigated the problems of ESP courses in Azad University, Iran, based on the perception of 102 Iranian ESP students (male and female). A questionnaire was the main instrument that was used in this study. The aim was to improve the ESP learning conditions in Iran by introducing some relevant recommendations for this issue and to inform teachers, textbook developers and policy makers that the ESP program needs more attention. There were three research questions related to the use of English in ESP classes, needs of ESP students in the ESP courses, and students' evaluation of their instructors. The results showed that English should be the medium of instructions; learners preferred the use of audiovisual aids, formative assessment is very important, and ESP instructors play a crucial role in conducting ESP classes.

Many researchers believe that teachers, who teach ESP courses, must be experts in the field. In other words, teachers who are not specialists in teaching ESP may play a significant role in the problems faced by learners. For instance, Hayati (2008) also investigated problems of an ESP program in Iran. In his study, he mentioned three main factors that are responsible for the emergence problems in ESP courses, and teacher specialization was one of these factors. Concerning this factor, he believes that teachers must be qualified enough in order to teach ESP courses.

Another problems that may cause obstacles for ESP learners can be caused by the ignorance of students' needs in ESP classes; for example, the types of activities and the interaction between students and teachers. Some researchers have investigated the needs of ESP students. Indrasari (2016), for example, conducted a study in Indonesia that aimed to detect the needs of physics students in ESP classes. There were 50 students who participated in this study and 4 ESP lecturers who taught ESP for physics students. Interviews and questionnaires were the main instruments that were used in this study. The findings suggested that the most students need is speaking activities in ESP and that most students preferred pair and group work activities. Knowing what learners need in ESP classes could minimize the problems that may face students.

Another study conducted in Umm-Alqura University, Saudi Arabia, aimed to shed light on students' needs in ESP classes is done by Alsamadani (2017). He conducted a study of 25 teachers and 200 ESP engineering students and was based on both qualitative and quantitative 
approaches. The instruments of the study were classroom observation, a questionnaire, and an interview. Additionally, one of the aims of the study was to provide empirical data related to various needs of engineering students in ESP classes. The researcher investigated the language skills and activities that were used in ESP classes and findings showed that receptive skills received more focus in the ESP classes for the engineering students. For example, reading activities took 110 minutes, which means that $27 \%$ of class time was devoted to reading activities, while $23 \%$ was allocated to listening skills. Speaking activities were given $20 \%$ of class time, while only $3 \%$ was dedicated to writing skills. Moreover, teacher talk was given more time than student-student interaction. The previous two studies give us indication of the importance of knowing students' needs in ESP classes, and that students did not have the opportunity to practice what they have learned in ESP classes since receptive skills were given more attention than productive skills.

Another issue that may cause a problem for ESP learners is the number of students in a classroom and several studies were conducted to discuss this problem. For instance, Suzani, Yarmohammadi and Yamini (2011) carried out a study on problems faced by undergraduates in the Iranian higher educational institutions. The study, which had 115 participants, revealed that large classrooms were a major source of problems because students could not concentrate on their studies and that some methods used by instructors were not appropriate. For example, students were not satisfied with the translation method (a list of terminologies translated into students' mother tongue) used by the instructors because they believed that they did not learn practical things in the course.

\subsection{ESP in Saudi Arabia}

Among the reforms introduced in the Kingdom of Saudi Arabia, ESP is central in English teaching. It has become a very necessary requirement for the undergraduates to have acquaintance with the field. The filed has attracted the attention due to various factors. The University of Taif devotes its utmost attention to ESP so that students could be adequately equipped with language skills required in specific jobs. The courses of ESP are calculated to enable the students to correctly communicate in English in educational and professional life. Therefore, they are formulated in accordance with the requirements of students. Furthermore, these courses are aimed to create required skills in the students that help them down the road. Such courses are taught in various institutions, such as business, science, medicines, etc. Globalization has made English global language (Kennedy, 2012). Now, the businesses prefer those workers who have sufficient knowledge of two or more languages. This has contributed to the need for ESP teaching across the world in a range of institutions.

That the ESP is a learner-oriented strategy to English, is another reason behind its importance. It is a unique approach because its main focus is to meet the needs of the students (Belcher, 2009:2). In China, the method of English teaching has been long denunciated for yielding scant outcome. Generally, it is motivation that paves the path for effective learning (Ellis, 1997). The main grievance of the Chinese students is that the colleges have failed to impart sufficient English skills to them (Fan, 2013). 
It aims to improve the learner's speaking and listening skills to a considerable extent (Cai, $2014 \mathrm{~b}$ ). And this is the third reason behind its significance. According to Hutchinson and Waters $(1987, \mathrm{p} 7)$, this attention to the communication is absolutely advanced. The content of the ESP emanates from a variety of fields (Strevens, 1988). ESP accords immense significance to the nexus between various subject areas in order to ensure that the language is taught in connection with different subjects in curricula. So, it can help accomplish this object. Through the connections, the students easily get acquainted with subject, techniques of analysis, and become motivated to learn (Brinton, Snow\& Wesche, 1989). Despite the fact that ESP is theoretically more effective than traditional English, the teachers invariably face the problem of creating subject-specific proficiency. Therefore, Hutchinson and Waters (1987, p159) graphically call them the residents of the land, unknown and unexplored. But the challenges always hold out opportunities, and we need to explore these.

English for Specific Purposes has been one of the most important areas in teaching English. The main aim of ESP courses is to meet the specific needs of students that will be needed in a specific area of the labor market. According to Hutchinson and Waters (1987), ESP "refers to an approach of language learning that is based on the needs of students". This study is an attempt to shed light on the challenges and problems that ESP learners face in general with reference to ESP students who study English for Business Administration at Taif University, Saudi Arabia. It has been noticed that at the end of every academic year, the results of the final exam of students, who study English for Business Administration at Taif University, are deteriorating and a big number of students fail this course. The reason that drives me to investigate this problem is that none of my colleagues have investigated this problem in this context. Thus, the main aim of this study is to explore the problems faced by students, who study English for Business Administration at Taif University, and provide recommendation for policy makers to incorporate into the learning environment for ESP courses to the students of Business Administration.

\section{Research Methodology}

This section of the research discusses participants, instruments, and the procedure. The interpretive approach employing semi-structured interviews was adopted. Participants in this study consisted of 5 Saudi male students, who study English for Business Administration at Taif University. Three of these students were repeaters, and the others were studying the course. The appropriate instruments that could achieve the aims of this study were interviews and documents (results of previous final exams). The questions of the interviews were constructed based on the information collected, the research questions, and the aims of the study. The documents used in this study showed that students who studied this course faced difficulties based on their final exam results. To fulfill the purpose of this study, interviews were recorded, then transcribed. And because participants' first language is Arabic and to make sure that the content of the interviews was understood by interviews, questions were translated to Arabic, then the discussion of the interviews was transcribed and translated to English. Furthermore, the documents that contain previous results of the final exams were 
used to show that there are continuous problems facing students studying this course.

\subsection{Research Questions}

This research attempts to answer the following questions based on students' perceptions:

RQ1: What are the challenges faced by ESP students in the department of Business Administration at Taif University?

RQ2: What are the possible ways of overcoming these challenges?

\section{Results and Discussions}

Based on the previous results of the final exams, it is obvious that students, who studied English for Business Administration faced many obstacles. For example, I was able to access to students' final exam results related to this course in the academic year 2016-2017 in Taif university. In fact, there were 81 students and 49 of them passed the course with great deal of difficulties. Thus, this section expressed the problems that were faced by students in that context. The results of the interviews are divided into two parts. The first part addresses the first research question regarding the challenges faced by students who study English for Business Administration, and the second part addresses the second research question regarding the possible ways of overcoming these challenges based on the perceptions of students.

\subsection{The Challenges Faced by Students}

According to the data extracted from the interviews, this part reveals the challenges that face the students.

\subsubsection{Large Classes}

All of the interviewees agreed that the large classes affect the process of learning in a negative way. For example, student "A" said that he could not concentrate in the lecture because of the big number of students, thus he could not fulfil the course requirement. In addition to that, students "B", "C, and "D" said, due to the big number of students in the class, they did not receive any kind of feedback on their assignments. Moreover, student "E" said "I failed this course last year because of many reasons and studying in a big class was one of these reasons. I hardly find a chance to participate in the class and the lecturer who taught me was not able to monitor my performance and give me feedback on my assignments".

\subsection{2 "Passages" Were the Only Source of Input}

The majority of interviewees claimed that the only source of receiving the lessons was through reading some passages. According to students"B", "C" and "E", the only material that was used during this course was passages and exercises related to these passages. They said that they did not have an opportunity to practice what they studied and all what they did in their class was reading a passage and then answering questions related to it. Additionally, student "C" said, "we need to have various inputs and we should be given an opportunity to 
practice the content of the course".

\subsubsection{Classroom Management and Teaching Strategies}

Three of the interviewees agreed that the way in which tasks of the lessons were done was not appropriate. For example, Student "B" said, "I prefer to work in group because I believe working with my colleagues makes tasks easier to understand". In addition to that, students " $C$ " and "D thought that doing tasks individually did not benefit them well because their instructor did not have enough time to provide feedback regarding their outcomes due to the big number of students, as they claimed. For students "A" and "E", working in groups or individually was not a big deal for them".

\subsection{The Possible Ways of Overcoming the Challenges Mentioned Above}

According to the perceptions of students, this part contains some ways that may help students to overcome the challenges faced by them.

\subsubsection{Minimizing the Size of the Class}

All of the interviewees strongly agreed that reducing the number of students in their classes would help them to overcome some of the challenges faced by them. Student "B", "C", "D, and "E" claimed that reducing the number of students would give instructors ample time to monitor and assess the performance of students. Moreover, student "A" said "if the number of students was reduced, I would easily concentrate during the lecture".

\subsubsection{Classroom Strategies}

Regarding the second problem that was mentioned earlier, student" B", "C" and "E" emphasized that having reading skill as the only source of input is not sufficient, thus they did not have a chance to practice the input they received. In fact, they agreed that they must be exposed to different teaching strategies. Moreover, learning how to speak and how to write would decently help them to have an opportunity to practice what they have studied. For students " $A$ " and " $D$ ", having reading skill as the only input was not considered as a challenge for them.

\subsubsection{Emphasis on Group Work}

For the third problem that face students regarding learning style, student "B", "C", and "D" believed that doing the tasks given to them in groups is the ideal way to help them accommodate the lesson. For instance, student "D" said "when I studied English in preparatory year, the instructor who taught me used to divide us into groups and we were asked to do the tasks given to us together. I had the opportunity to share my ideas with my group members and we learned from each other. I think if we follow the same procedure in this course, my performance will improve since I have the opportunity to exchange knowledge with my colleagues". 


\section{Discussions}

Based on the results of this study, the challenges that face the learners can be categorized into three main problems: (1) large classes, (2) neglecting productive skills, and (3) Classroom Management and Teaching Strategies. Regarding the first problem, all of the interviewees argued that large classes was one on of the significant problems they faced. Yelkpieri, Namale, Esia-Donkoh, and Ofosu-Dwamena (2012) conducted a study that revealed the negative effects of large classes based on the perception of both teachers and students. Students thought that large classes may prevent lecturers from improving the performance of weaker students. Moreover, teachers claimed that contributions in large classes were done by the minority of students. In addition to that, this problem was found in a study conducted by Suzani,Yarmohammadi and Yamini (2011) in Iran. It showed us that large classrooms prevent learners from concentrating on their study. Additionally, one of the disadvantages of large classes is that teachers seemed to be unable to provide feedback for their students. Thus, we can argue that minimizing the size of classes will allow students to concentrate well and receive feedback from their instructors. Concerning the second problem, three of the interviewees complained the teaching strategy of their instructor was very limited to reading task-based learning only. According to them, they did not have an opportunity to practice what they studied. It seems that the only skill that was used was reading and this gives us a big indication that productive skills were not used at all, which means students did not have the opportunity to practice the input they received and there is no guarantee that the input is understood. Because students could not provide any kind of output, it is very difficult for teachers to assess the performance of their students and give feedback. Input and output are part and parcel of the process of learning and cannot be separated, thus, the availability of output is a must for students in order to be assessed and given feedback. Many researchers believe that learners must understand the input they receive by communicating with each other. For example, Shehadeh and Coombe (2010) said, "negotiation of meaning and modification of input are necessary for L2 learning". This means that students must understand the input in order to produce an output. A study that was conducted by Indrasari (2016) showed that what students really need in ESP classes is speaking activities and this assures that receptive skills and productive skills are integrated. Furthermore, the variety of input is important for students to accommodate the lesson, so having passages, as the only source of input is not sufficient. In their study, Tabatabaei and Mokhtari (2014) argued that learners preferred the use of audiovisual aids in ESP classes. Classroom Management and Teaching Strategies were part of the problems that students faced in ESP classes. Three of the interviewees agreed that doing tasks in groups is better than do it individually. In a study that was conducted by Indrasari (2016), the results of the study showed that most of the students, who participated in this study, preferred pair work and group work in ESP classes. This emphasizes that working in groups is more effective than working individually. Moreover, Shehadeh (2004) claimed that task-based pair and group activities allow students to be involved in the process of learning. In this context, allowing students to do tasks in groups will help both instructors and students. On other word, Instructors will have the opportunity to monitor their students and give them feedback, and students will have a great chance to exchange knowledge with each other. 


\section{Conclusion}

This study presented the major problems that face students, who study English for Business Administration in Taif university, Saudi Arabia. It revealed that there are three problems that form a big challenge for students. The first one is about the big size of classes and the second one is related to the limitation of the input and the third one is related to learning style and interaction between students. Additionally, this study presented solutions for these problems based on the point of view of the students who participated in this study. Identifying the problems and knowing the solutions will definitely make teachers aware of the needs of the students and as a result, students will be able to study with ease.

\section{References}

Alsamadani, H. A. (2017). Needs Analysis in ESP Context: Saudi Engineering Students as a Case Study. Advances in Language and Literary Studies, 8(6), 58-68.

Belcher, D. (2009). What ESP Is and Can Be: An Introduction. In D. Belcher (Ed.), English for Specific Purposes in Theory and Practice. Ann Arbor: University of Michigan Press.

Brinton, D. M., Snow, M. A., \& Wesche, M. B. (1989). Content-based Second Language Instruction. Boston: Heinle and Heinle Publishers.

Cai, J. (2014a). Form EGP to EAP---Restoring the Essential Status of College English Teaching, Foreign Languages and Their Teaching, 1, 9-14.

Ellis, R. (1997). Second Language Acquisition. Oxford: Oxford University Press.

Fan, L. (2013). The Reform of English Aiming at Solving the Embarrassment of Dumb English,Wenhui Newspaper, 8/3/2013.

Hayati, A. M. (2008). Teaching English for Special Purposes in Iran: Problems and suggestions. Arts and Humanities in Higher Education, 7(2), 149-164.

Howatt, A.P. R. (1984). A History of English Language Teaching. Oxford: Oxford University Press.

Hutchinson, T., \& Waters, A. (1987). English for Specific Purposes. Cambridge: Cambridge University Press.

Indrasari, N. (2016). English for Specific Purposes: A Need Analysis at The Second Semester of Physics Education Students of IAIN Raden Intan Lampung in The Academic Year of 2015/2016. English Education. Jurnal Tadris Bahasa Inggris IAIN Raden Intan, 9(1), 161-172.

Kennedy, C. (2012). ESP Projects, English as a global language, and the challenge of change. Proyectos de IFE, inglés como lengua global y el desafío del cambio, 24, 43-54.

Paltridge, B., \& Starfield, S. (2013). The handbook of English for specific purposes. Chichester: Wiley-Blackwell. 


\section{Macrothink}

Shehadeh, A., \& Coombe, C. (2010). Introduction: From theory to practice in task-based learning. Applications of Task-Based Learning in TESOL, 1-7.

Shehadeh, A. (2004). Modified output during task-based pair interaction and group interaction. Journal of Applied Linguistics, 1(3).

Strevens, P. (1988). ESP after twenty years: a re-appraisal. In M. Tickoo (Ed.), ESP: State of the Art. Singapore: SEAMEO Regional Language Centre. 1-13.

Suzani, S. M., Yarmohammadi, L., \& Yamini, M. (2011). A Critical Review of the Current Situation of Teaching ESP in the Iranian. The Iranian EFL Journal, 36(3), 179.

Yelkpieri, D., Namale, M., Esia-Donkoh, K., \& Ofosu-Dwamena, E. (2012). Effects of Large Class Size on Effective Teaching and Learning at the Winneba Campus of the UEW (University of Education, Winneba), Ghana. Online Submission.

\section{Copyright Disclaimer}

Copyright for this article is retained by the author(s), with first publication rights granted to the journal.

This is an open-access article distributed under the terms and conditions of the Creative Commons Attribution license (http://creativecommons.org/licenses/by/3.0/). 